\title{
Memoria, verdad y ambigüedad. Píndaro y el kairós de los poetas.
}

Senda Sferco*

Resumen: El presente trabajo aborda la temática de la temporalidad ligada a la producción de relatos de memoria en la antigua Grecia, cuando esta tarea era encomendada a la creación de palabra en boca de los poetas. Mediante un estudio de las odas y de los epinicios de Píndaro (518 a.C.-543 a. C) -tanto en el contexto de su surgimiento como a través de interpretaciones filosóficas posteriores-, los relatos plausibles de conformar una memoria aparecen ligados a un acto de composición selectivo, donde el poeta decidirá qué acontecimientos serán dignos de Elogio y cuáles, en cambio, de Vituperio. En un contexto que se asume complejo, constituido por fuerzas ambivalentes, las producciones de palabra al servicio de un sostenimiento de la memoria deberán sortear siempre la opacidad de las circunstancias que la confunden, la ironizan, la amenazan de olvido. La palabra, así, en boca de los poetas, tendrá la eficacia capaz de dar cuenta de una economía de lo verdadero que ya va trazando la memoria de las paradojas de su propia historia.

Palabras clave: temporalidad, memoria, producción de palabra, producción de verdad

Abstract: This paper addresses the issue of temporality linked to the production of memory narratives in ancient Greece, when this task was entrusted to poets and their creation of words. Through a study of Pindar (518 BC - 543 BC) Odes and Epinicia both, in the context of its emergence as through further philosophical interpretations- plausible stories to form a memory appear linked to a selective act of composition, where the poet decides what events will be worthy of Praise, and which, instead, of Shame. In a context that is assumed complex, consisting of mixed

* Investigadora Asistente del CONICET, Doctora en Filosofía (Paris VIII) y Doctora en Ciencias Sociales (UNQ), licenciada en Antropología (UNR) y post-titulada en Estudios culturales y artísticos en la STSI-ISI (Bali, Indonesia). Ha desarrollado investigaciones del pensamiento filosófico y político contemporáneo, especialmente en relación a la obra de Michel Foucault, Gilles Deleuze, Walter Benjamin y Giorgio Agamben. Correo electrónico: senda.sferco@gmail.com 
forces, word productions serving a sustaining memory must always overcome the opacity of the confusing circumstances, the irony, and the threat of oblivion. Words, in the voice of the poets, will become the efficacy marks of some kind of economy of the truth that is already mapping the paradoxal memory of its own history.

Key words : temporality - memory - word productions - truth production

\section{Introducción}

¿Cómo asegurar el vínculo de la palabra con lo verdadero?, pregunta Píndaro por boca de los poetas que cantan sus versos inspirados por las musas.

Pocas veces el problema de la verdad revistió características tan peculiares como cuando ocupa la voz de los poetas del siglo V griego. En la tarea de mantener vivo el orden de legitimidades propio del mundo mítico que la búsqueda democrática de la polis irá solapando progresivamente con otras discursividades-, los poetas toman la palabra para ratificar la importancia de sostener una inventiva al servicio de las asignaciones vigentes. La creatividad de sus composiciones tiene esa función conservadora. En medio de las aventuras que reúnen los epinicios y las odas, el canto de los poetas es un canto cuya inspiración divina asegura la producción de una palabra verdadera, que sosteniéndose frente a la infinita volatilidad de lo perecedero, en el mismo movimiento en que dice hace una memoria digna de ser recordada.

Situada en un contexto de circunstancias heterogéneas, la tarea de los poetas se presenta como una actividad selectiva al servicio de una producción de verdad. Esta cuestión nos obliga a preguntar: ¿cuáles son los hechos que merecen ser cantados? ¿Qué medios se ponen en movimiento a la hora de definir qué es digno de ser recordado y qué permanecerá para siempre en el olvido? ¿Sobre qué criterios se toma esta decisión selectiva?

El mundo arcaico griego sin duda ofrece varias pistas para adentrarnos en la complejidad de estos interrogantes. En la "pre-historia" del reinado de lo escrito, los relatos orales narrados por los reyes, los adivinos y los poetas van marcando el ritmo de los acontecimientos dignos de conformar el 
archivo de una memoria. Sus versos operan diciendo y produciendo particiones: algunas palabras serán recordadas y repetidas una y otra vez sosteniendo su brillo en el tiempo; otras, permanecerán sin decirse sedimentando la negra noche del olvido.

El asunto no es cosa menor cuando estas palabras se unen en la tarea de escribir una memoria común y cuando su transmisión compromete, además, la suerte de una biografía a la que no le es prometida vida eterna como es el caso del destino humano después de la muerte en el mundo griego arcaico. Los versos del poeta clásico griego Píndaro (518 a.C.-438 a.C.) conformarán, en este sentido, una clave de lectura de los modos en los que estos juegos de memoria y de verdad sortean su suerte en las manos de los poetas en este tiempo. A través de ellos podremos remarcar cómo la "medida" que opera estas particiones se articula conjuntamente con el diagnóstico del entramado de una coyuntura, momento complejo, a la vez singular y regulativo, cualitativo y crítico, que -tal como veremos-, los griegos explican en términos de kairós. En un tiempo en donde la verdad aún no precisa legitimar sus operaciones garantizando la estabilidad de un principio de no-contradicción, donde la verdad todavía puede dirimir sus decisiones entre posiciones ambivalentes, la palabra acapara un lugar central -el único lugar posible en la lógica holística del mito-, marcando con su decir el ritmo de un vínculo memorable con lo verdadero.

Pocas tareas unirán tan intrínsecamente palabra y verdad como la actividad de los poetas en el mundo griego arcaico, donde decir es hacer, donde ley, razón y discurso se reúnen más que nunca en la dinámica del logos para consolidar la dirección de su fuerza interpretativa.

\section{La verdad como juego entre ambigüedades}

Lejos de asimilarse a una naturaleza estabilizada en una esencia, la verdad es un asunto que participa de múltiples juegos en el mundo arcaico griego. En una escena conducida por la lógica de complementos propia del mito, donde lo conveniente y lo inconveniente, lo favorable y lo funesto, lo justo y lo injusto, lo vital y lo mortal, lo claro y lo oscuro, se exhiben siempre conformando pares complementarios e indisolubles, la verdad se afirma en la 
dinámica práctica que va marcando una mirada atenta a sus aporías. Verdad es entonces lo que resulta de un juego, es eso que adviene cuando se busca establecer, en medio de las mezclas de las circunstancias, un criterio regulado a la vez que móvil, capaz de imponer y de reformular, en cada momento y en cada situación, el alcance de su necesidad según la coyuntura de su oportunidad.

Tomada por la fuerza del logos, la verdad adviene ligada a la posibilidad de tomar la palabra. En su ensayo Les Maîtres de Vérité dans la Grèce archaïque, Marcel Détienne (2006) explica que los modos de detentar esta capacidad no siempre fueron los mismos: en las profundidades de nuestra historia, concretamente en los restos de materiales micénicos y babilónicos que nos ha legado la Grecia arcaica, tanto el adivino, el rey, como el poeta compartían una misma posibilidad de producción de palabra. Las tres figuras guardaban un mismo poder de palabra. Se trata de una palabra mántica, sagrada, que según cuentan las fuentes, llega a ellos como fuerza, como inspiración, como memoria -Mnémosine. Esta fuerza sagrada les permite percibir lo invisible haciendo de este don la facultad de una producción de visión total: ellos pueden decir lo que ha sido, lo que es y lo que será, porque pueden verlo. La configuración de su decir pauta los límites del mundo. Sus palabras son acciones que, cada vez, re-crean el mundo, esto es, el mundo tal cual es, el único mundo posible; así es la fuerza fundadora del mito.

En esta herencia, la verdad de un logos de alguna manera también asegura una justicia de discurso. De este modo, decirla es transmitir y confirmar la luminosidad y el brillo de una fuerza vital, de una plenitud divina que inspira tanto el canto de los poetas celebrando las acciones humanas realizadas con heroísmo como las virtudes oraculares de los procedimientos ordálicos, a través de los cuales los reyes y los adivinos hacen justicia. Ni uno ni otro proceso requieren de la argumentación o de la confirmación de sus pruebas. Las cuestiones humanas todavía no precisan deliberarse por fuera de la acción que en su decir traen aparejada, ya que palabra y acción forman parte de un mundo en el cual los dioses son quienes siguen legitimando todas sus posibilidades. El logos arcaico pone en boca de los hombres una palabra que es, en primera y en última instancia, siempre producción divina. El orden del mundo ya está pautado, y, en efecto, son los dioses quienes inspirarán las 
pronunciaciones de los poetas, encargados de mantenerlo y de perpetuarlo. Mnémosine, la memoria, aparece como la figura de esta presencia divina en el orden humano.

\section{El canto del poeta, entre el elogio y la ironía}

La tarea del poeta, sin embargo, no es en absoluto simple: no podría transmitir las palabras de los dioses a los hombres sin tener que sortear, primero, la multiplicidad de condiciones que acechan en las circunstancias, fuerzas singulares que también forman parte de la potencia divina así como de la condición humana en este mundo. El poeta, deberá desarrollar la capacidad discursiva (esto es, la habilidad de un uso del lenguaje, pero también, del manejo de sus cadencias, de sus timbres, de sus pausas y de sus ritmos) para producir y para proteger una palabra que pueda sostenerse en el tiempo sin caer en el olvido. Sólo la luminosidad de la memoria permite sostener un discurso en medio de situaciones esquivas y caminos sinuosos llenos de recovecos. En un mundo sin miedo de asumirse opaco y perecedero, la palabra permanecerá a salvo como memoria, únicamente si participa del cortejo sintagmático de Alétheia.

Este hecho es genealógicamente interesante ya que, precisamente, Alétheia -explica Détienne (2006) analizando las herencias micénicas y babilónicas del mundo arcaico griego-, antes de volverse una suerte de predicado filosófico monódico para el develamiento de lo verdadero, era una potencia solidaria de un grupo de entidades religiosas cuyos efectos semánticos se mostraban asociados y opuestos a la vez. Por su proximidad con Diké, la Justicia, Alétheia se emparentaba ante todo con la idea de Luminosidad y de Alabanza. Al mismo tiempo, Alétheia contrastaba con Lethé, Olvido, cómplice de la fuerza del Silencio, de la Calumnia y de la Oscuridad. Ambos - Alétheia y Lethé- eran productos de Mousa, la potencia desbordante de lo humano que se halla en la palabra cantada. Tanto la palabra memorable de Mnémosine como la palabra irónica de Momos se encuentran en la raíz de las fuerzas que movilizan esta inventiva. Sin embargo, en el centro de esta configuración mítico-religiosa, las enunciaciones de Alétheia permitían marcar el pulso de la pronunciación de una verdad asertórica: su palabra es fuerza 
eficaz, es potencia creadora de ser $^{1}$; sus modulaciones son rayos que atraviesan un mundo de ambigüedades para seguir sosteniendo, ontológicamente, el régimen decisivo de su brillo.

En este pensamiento, Alétheia y Lethé no se excluyen ni contradicen ; son los polos de una sola y misma potencia religiosa. La negatividad del Silencio y del Olvido forma la sombra inseparable de la Memoria y de la Alétheia. Es en nombre de la misma potencia que las Musas, hijas de Memoria, saben a la vez "decir verdades y cosas engañosas que se asemejan a realidades"2.

Reencontrándose en la tensión entre el fulgor de verdad y la errancia del olvido, Alétheia y Lethé son las dos fuerzas complementarias que anudan y condensan el universo de significantes que dinamiza esta atención tomada por lo ambivalente. La luminosidad vital de la Alétheia y la oscuridad mortal de Lethé marcan, antes que una contradicción, una aporía: ninguna de ellas podría existir sin la otra y el trazo del límite entre las dos es tan arbitrario como vulnerable la finitud humana.

No hay de un lado Alétheia $(+)$ y del otro Lethé (-), sino que entre estos dos polos se desarrolla una zona intermedia donde Alétheia se desliza hacia Lethé y viceversa. La "negatividad" entonces no está aislada, apartada del Ser ; ella desdobla a la "Verdad", es su sombra inseparable."3

En la tensión de esta aporía, el destino humano confiesa su insondable abismo; su suerte sólo puede jugarse manteniendo el trazado de cierta estabilidad a través del movimiento. Entre ambivalencias irresolubles, la vOz de los poetas se presta a dar cuenta del errabundeo que sortea toda palabra abriéndose paso en medio de una opacidad de olvidos, vituperios e ironías. El canto de los poetas completará su obra cuando pueda hacer presente a Mnémosine y a Alétheia en sus versos y en el corazón de su auditorio.

${ }^{1}$ Cfr. Detienne, Marcel Les Maîtres de Vérité dans la Grèce Antique, Paris, Ed. Le Livre de Poche, Librairie Générale Française, 2006, p. 8.

${ }^{2}$ Hésiode, Théogonie, 27-28 en Détienne, M., op. cit., p 9. Traducción propia.

${ }^{3}$ Détienne, M., op. cit., p 45 . Traducción propia. 


\section{La "palabra-eficaz" de los poetas}

Tomada por la lógica del mito, la palabra siempre inaugura, ratifica, configura un determinado mundo. En este contexto, como ya dijimos, la palabra no se somete a discusiones, ni debate sus ordenamientos (como ocurrirá más tarde en la escena de negociaciones de la polis). En este punto, se requiere en cambio de una "palabra eficaz"; palabra que tiene el desafío de sostenerse siempre en el borde crítico de los dobles que la componen -lo oscuro y lo claro, Lethé y Alétheia- (aunque no todavía la problemática de identificar y de deliberar sus contradicciones ${ }^{4}$ ). Lidiando entonces en medio del "entre" marcado por el "cada vez" de la oposición de sus complementos, "la" palabra eficaz será el rayo que ratifique en cada una de las diversas contingencias el sostén legítimo del mundo. Son los poetas, definitivamente, quienes reciben este fulgor de rayo divino. Son ellos quienes, por medio del ritmo de sus fraseos, de la cadencia de sus versos, de la métrica de su canto, ponen en marcha los elementos que conforman el material de moldeado de lo verdadero bajo el brillo de la Alétheia. Ciertamente, el desarrollo de cierta agilidad deviene clave para asegurar una eficacia provechosa en un mundo difícil, complejo de brillos y oscuridades. Por lo tanto, será necesario movilizar una economía de movimientos que evite las confusiones de la errancia sin alterar la vigencia del mundo tal cual es. ¿Cómo asegurar, en consecuencia, cuáles son los mejores trayectos? ¿Cómo identificar el pulso que rige la dinámica de la Alétheia? ¿Con qué herramientas asegurar el sostenimiento de su equilibrio en medio de un contexto complejo y de condiciones continuamente cambiantes?

${ }^{4}$ En este punto recuperamos la hipótesis vertebral del autor (Détienne, 2006), para quién el pasaje del mundo arcaico al mundo clásico está atravesado por una lógica de verdad dónde Alétheia/Lethé (pero también palabra y acción) serán pares complementarios conviviendo en una ambivalencia irresoluble que luego el mundo clásico barajará en términos de pares contradictorios. Tal la imagen del carro dorado del poema de Parménides, donde la Verdad, investida únicamente de luminosidad, proclama: "el ser es y el no ser no es". 


\section{Las flechas emplumadas de kairós}

El mundo arcaico griego va distribuyendo el material de lo verdadero entre sus fuerzas complementarias. Varias nociones y figuras se ocupan de marcar los criterios de referencia para realizar las clasificaciones que necesita este mundo. Así, en tanto fuerzas abocadas a la difícil tarea de ratificar la reproducción de la lógica explicativa del mito, los diversos sintagmas de una producción conceptual -Alétheia, Dikée, metra, mesón, summetria, akmé, por nombrar tan solo a los más importantes- se unen entre sí en el esfuerzo de circunscribir la multiformidad de las cosas del mundo a un horizonte de verdad. Lo verdadero, lo justo, lo armónico, recordemos, comprometen la tarea humana en una búsqueda constante del equilibrio, punto medio, mesón, pico cumbre de una lógica distributiva, proporcionada y crítica.

En esta dinámica, pocas figuras condensan la fuerza semántica de los significados habilitados por estos sintagmas como lo hace la noción de kairós. Figura alada que encarna la fuerza del tiempo cualitativo, kairós adviene, cuenta el mito, según producimos y vamos aprovechando las oportunidades. Noción que permite tejer puentes entre mundos disímiles, es la imagen de un aleteo divino siempre presente en el contexto de los hombres. Esta doble filiación tiene efecto en el acontecer ambivalente de sus significados: kairós es, a la vez, el trazo recto de una luminosidad divina que busca sostener el orden del mundo tal cual es, al mismo tiempo que la multiplicidad de marcas mutables propias de la dinámica desigual de las circunstancias. Kairós, figura de mezclas, es la pieza que va pautando la composición práctico-discursiva que habita toda coyuntura.

Cuenta el trazado de su etimología que sus primeras apariciones

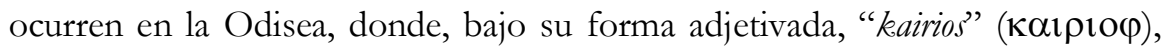
esta figura viene a marcar un "punto crítico" en determinado espacio. Con este vocablo se nombra, por ejemplo, a los intersticios que crean el "defecto de la armadura" por donde Héctor, en el relato homérico, encuentra la 
muerte. En esta línea de significación, Onians ${ }^{5}$ (1996) y Gallet ${ }^{6}$ (1990) también refieren con el mismo nombre al huso que mantiene las proporciones entre los hilos de un telar posibilitando un tejido. En ambos casos, kairós es la clave de un atravesamiento espacio-temporal cuya estrategia de paso siempre produce efectos.

Este recorrido estratégico de espacios y de tiempos aparece sintetizado en una figura que nos lega la poética de Píndaro: la imagen del arquero tirando de la flecha, a propósito de la cual el poeta utiliza la fórmula

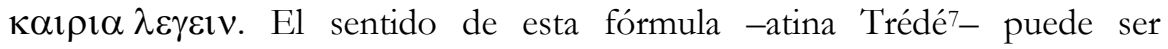
traducido como "decir cosas decisivas". Amalgamadas por la metáfora, palabra y flecha se hacen una en el trazo del poeta. En efecto, esta idea de la palabra como "proyectil" puede registrarse en varios pasajes poéticos y trágicos ${ }^{8}$, remitiendo siempre a la antigua metáfora homérica de las "palabras emplumadas": la palabra es un "proyectil" y, por analogía, el poeta "lanza" sus cantos como flechas que van directo al objetivo: "Ve, corazón mío, que tu arco apunta ahora al objetivo./¿A quién golpearemos con estas flechas de gloria / que lanza nuestro espíritu vuelto clemente?"9

De esta manera, lanzando proyectiles directos ${ }^{10}$ el poeta de palabra franca ${ }^{11}$ llega al objetivo. Podríamos multiplicar las asiduas referencias al uso de este sentido que funden en una misma figura al arquero y al poeta. Sin

5 Onians, J. Arte y pensamiento en la época helenística: la visión griega del mundo (350 A.C.-50 A.C.), Barcelona, Editorial Alianza, 1996.

${ }^{6}$ Gallet, B. « Recherches sur kairós et l'ambiguïté dans la poésie de Pindare », Paris, Presses Universitaires de Bordeaux. 1990

7 Trédé, Monique. Kairós. L'à-propos et l'occasion (Le mot et la notion, d'Homère à la fin du IV e siècle avant J.-C.). París, Éditions Klincksieck, 1992, p. 41.

8 El verso 446 de Las suplicantes de Esquilo hace recurso a esta figura, al evocar metafóricamente a la "lengua que lanza tiros que no son los decisivos". También Píndaro despierta una imagen similar exclamando en el Ístmico, $V$, v. 46 y ss.: “...numerosos son los golpes que mi lengua verídica puede lanzar en su honor".

9 Píndaro, Píticas, IV, 270.

${ }^{10}$ Cfr. Píndaro, Olimpicas, XIII, 93.

${ }^{11}$ Cfr. Píndaro, Piticas, II, 82. 
embargo, más que un relevamiento filológico, lo que nos interesa remarcar aquí son los efectos implicados por la puesta en valor de kairós al servicio de una "palabra franca" o una "palabra eficaz" en donde decir y hacer se vuelven una y la misma cosa.

Tal como lo expresa Píndaro en las Piticas, Kaıpov $\varepsilon 1 \phi \theta \varepsilon \gamma \chi \alpha 1$, esta misión, que nos animamos a traducir como "que nuestras palabras alcancen su objetivo", sintetiza el rol fundamental de los poetas en esta época. De esta manera, parafraseando el gesto de los arqueros adiestrados en el arte de la guerra, producir una palabra capaz de llegar a término implica tensar un arco abarcador de varias posibilidades y, en ese rango de visión, arriesgar el lanzamiento de una flecha dirigida hacia un objetivo preciso. Lo interesante del trayecto de este logos es que no puede completarse nunca sin tener que sortear su suerte entre otras palabras, entre la ambivalencia que se afirma entre sus ironías y su necesidad de elogio. Frente a la eficacia tajante de su recorrido de verdad, las otras palabras, vanas, caerán en la tierra al igual que tiros de flecha mal lanzados. La diferencia que marca el destino de una y otra palabra viene pautada por la capacidad de articular en un decir-acción el momento oportuno de su ejecución. El arte del manejo de kairós deviene así garantía de eficacia de producción de lo verdadero.

\section{Kairós como criterio económico-estético}

Lanzamiento eficaz y producción veraz amalgamados en un mismo movimiento. Un criterio de unificación comienza a ser necesario. La filóloga Monique Trédé (1992) subraya esta trama sin dudas importante, ya que como consecuencia del lanzamiento de las palabras-proyectiles directas al objetivo, se hace presente en este contexto de referencias la relación con cierta economía de movimientos que luego devendrá clave en el manejo de kairós. Se precisa cierta "concisión" en el trayecto del proyectil-discurso, de lo contrario, la flecha se perderá en la travesía y no podrá dar con su objetivo; la cuestión de 
la "eficacia" deviene entonces un asunto de economía12. En este sentido, es preciso considerar que la palabra eficaz del poeta deberá sortear convenientemente la multiplicidad de circunstancias que presenta la poikilia. En este sentido, Píndaro evoca imágenes que dicen de la necesidad de "ordenar" la enmarañada materia en la que escribe sus versos: habla de tomar "caminos derechos y rápidos" 13 , del "carro en carrera que sigue derecho su ruta"14, del "navío al que los vientos dirigen recto hacia el puerto"15, reproduciendo la metáfora náutica que atraviesa el mundo griego arcaico, donde la tarea de equilibrio del alma y de conducción de gobierno se asemejan al pilotaje de un navío sosteniendo la dirección de su rumbo -re-situando-, cada vez, en medio del oleaje, cambiante, riesgoso, las posiciones de su timón y de su brújula, incapaz de controlar nunca acabadamente el acaecer de las circunstancias.

Tal como nos recuerda Trédé (1992), estas imágenes dan cuenta tanto de las dificultades que supone componer una poesía en clave policromática como del carácter inestable propio de la inspiración poética ${ }^{16}$. Al respecto, puede resultar ilustrativo recordar que el "epinicio" -una forma literaria propia de los himnos y de las odas- es un género que regula restricciones temporales y espaciales. Este aspecto es importante, ya que, a la par, existen otros tipos de poesías - por ejemplo, la poesía épica- que pueden hacer gala de un tiempo distendido, contando historias pormenorizadas en la descripción de sus detalles. El poeta lírico, en cambio -como Píndaro-, no puede decirlo todo y sus odas usualmente se recitan en ocasión de fiestas donde toda la ciudad se encuentra reunida para homenajear al elogiado. La cuestión

12 No sólo la poesía sino también la tragedia proveerá, a su vez, ejemplos similares: Sófocles, en su Electra, también subraya este hecho: "Prête à mes propos une oreille attentive, et, si je manque le but, redresse-moi” (Cf. Trédé, M., op. cit., p. 44). También Eurípides, en las Fenicias, 469 y ss., donde Polinicio opone la palabra verdadera a los retorcidos discursos de los Sofistas: "Simple est le langage de la vérité. Une cause juste n'a pas besoin de subtils commentaires : d'elle-même elle touche au but" (Cf. Trédé, M., op. cit., p. 44).

${ }^{13}$ Cf. Némeas, I, 25-26.

14 Cf. Piticas, XI, 39.

15 Cf. Olimpicas I, 110-112.

16 Piticas, IV, 110-111. 
de su extensión queda entonces circunscrita a los tiempos pautados por la situación de una ceremonia cívica, cuyo ritual se despliega siempre bajo condiciones que es preciso respetar. Así, el poeta coral, cuidadoso, debe siempre atenerse a una medida del tiempo: "Decir todo largamente, la ley de la oda y el tiempo que apremia lo impiden"17

Decíamos, el elogio a la rapidez y a la "brevedad" deviene una suerte de principio de economía en la obra de Píndaro. Pero también, la producción de una palabra eficaz debe atenerse a requisitos estéticos. Kairós -tal como nos muestra la evocación de los versos de la IV Pítica de Píndaro-, reúne en un solo movimiento las necesidades económico-estéticas de la producción poética apaciguando con sus versos la bybris del poeta apasionado, proponiéndole tomar una "vía más corta" que le permita, en toda situación, preservar el brillo de Alétheia: “....sería demasiado largo volver por la ruta empedrada ( $\alpha \tau \alpha \mu \mu \alpha \chi \imath \tau o v)$; la hora apremia y conozco un sendero más corto (ourov $\beta \rho \alpha \xi u v)$. A muchos otros he también sabido mostrar la voz del genio"18

El estilo rápido y elíptico de la oda contrasta con el paso lento y marcado del relato épico, caro a los poetas más antiguos. De la mano de kairós, la palabra repasa eficazmente su manejo del mundo sin desdecirlo. Kairós permite al poeta desarrollar un dominio del ritmo, de las interrupciones, del uso de metáforas y evocaciones; sus frases dan lugar a una transición ligera, en tanto, sincopadas por un juego de volúmenes y silencios, van constituyendo en su decir una poesía siempre en movimiento. (De hecho, Píndaro gustaba provocar a los escultores de su tiempo oponiendo sus odas a la rigidez inmóvil de sus obras).

\section{Kairós en el montaje poético}

\footnotetext{
17 Cf. Némeas, IV, 33-34.

${ }^{18}$ Píndaro, Píticas, IV, 110-111.
} 
Varios autores han expresado que la particularidad de la poesía de Píndaro es que "nace de la ocasión"19. Aparentemente, sus versos se habrían compuesto en relación al material que fueron proporcionando las variadas circunstancias, ofreciéndonos odas y epinicios cuyos matices permiten vislumbrar un paisaje entremezclado, de composiciones polimorfas y de matices decisivos. Píndaro, poeta del kairós, asegura el acontecer de su fuerza semántica (corte, punto medio, separación, distribución, decisión, crisis...), produciendo sus versos a partir de materiales y de contextos diversos.

"El destello de los himnos de alabanza vuela como la abeja de un asunto a otro" 20 . La filóloga Monique Trédé (1992) analiza estos versos que se encuentran en las X Píticas, una de las primeras odas que compone Píndaro, alrededor del año 498 a.C. Comparando el poeta a la abeja que sobrevuela y picotea aquí y allá buscando polen para producir su miel -tal como lo relataba el mito de las mujeres abejas de Hermes ${ }^{21}$, el joven Píndaro busca subrayar la diversidad de la poesía coral incorporando la multiplicidad de sus elementos en el ritmo de sus creaciones. Sólo de esta manera, la poikilia puede participar de la Alétheia. De no contar con el arte de las selecciones que realizan los poetas por medio de su toma de palabra, esta diversidad permanecería como mero desorden. Una vez más, la llave que articula las circunstancias a la palabra tiene el nombre de kairós. Ésta es la clave de una selectividad que, trabajando en función de una armonía, facilita al poeta extraer "la más fina flor" en todos los motivos que se ofrecen frente a él. La armonía se compone solamente a partir de un mosaico de temas y de

${ }^{19}$ Cf. Untersteiner, M. "Kairós come fonte del fatto poetico", en La Formazione poetica di Pindaro. Messina, Firenze, Casa Editrice G. D'Anna, 1950, pp. 65-102.

20 Píndaro, Piticas, X, 53

${ }^{21}$ Las mujeres-abeja o la imagen de las tres vírgenes aladas, encarnan, en la mitología griega, a las musas que con su vuelo y su palabra van creando las distintas cosas de la realidad. Estas tres hermanas inventan la realidad al mismo tiempo que instauran lo verdadero, y no efectúan esta tarea en un movimiento lineal sino arborescente, discontinuo, azaroso. Según cuenta el mito, Hermes recibe de Apolo una suerte de cetro investido de este poder de palabra-eficaz, con éste podrá producir, seleccionando aquí y allá los distintos materiales de las circunstancias, los más justos juicios de palabra. 
imágenes que emergen siempre yuxtapuestos. En ese espesor, en esa superposición de elementos, es donde el poeta debe encontrar el punto justo, el kairós de su obra. Decisivamente, el arte poético no podría sino concebirse como arte de cortes y rejuntes a la vez.

Con este gesto Píndaro permite hacer frente a las figuraciones clásicas que aluden a la creación poética como algo que debe escindirse de la opaca materialidad de las circunstancias. Su pluma, en cambio, reivindica la presencia (y la fuerza constatable) de la multiplicidad de las contingencias que se reencuentran entremezcladas al interior de cada una de sus odas. Los poemas, así, son "un cráter de cantos inspirados por las Musas que mezcla el poeta." (Ístmicas, VI, 2). Dichas "mezclas" (krasis, en griego) también tienen a kairós como criterio selectivo (etimológicamente, además, ambos vocablos comparten la misma raíz *krr, que denota la idea de corte, de selección, de crítica). De hecho, el poeta no tiene más que seguir el ejemplo de las Musas, visto que, en definitiva, no son sino ellas quienes saben "reunir el oro con el marfil blanco y separar a la flor de lis del rocío de la mañana" (Nemeas, VII, 78, 79). Recordemos, Mousa refería al espíritu desbordante de lo humano, pudiendo tomar la forma tanto de Mnémosine, al servicio de la luminosidad de la Alétheia, como del sarcasmo irónico de Momos, hijo del oscuro Lethé. Hacedor de los entremedios de este mundo de parejas complementarias, el poeta pone su talento al servicio de ensamblar los diversos elementos del mundo en un poema, que se yuxtaponen y funden, al igual que se liga "la leche con la miel" (Píndaro, Nemeas, III, 77). En la prehistoria de occidente, la producción poética se asume como tarea de un montaje, de una construcción entre bordes que precisa por igual la participación de imágenes, motivos, relatos, sonoridades y ritmos.

\section{Salvaguardar la memoria de lo verdadero}

En el breve estudio que desarrollamos hasta aquí la producción de palabra en boca de los poetas tiene la peculiaridad de ir habilitando un vínculo selectivo con lo verdadero que permite componer un relato memorable. Hablamos de una memoria oral, cantada una y otra vez, reiterando su selección contra las mutaciones del paso del tiempo. En un 
mundo aún no dominado por la escritura, vimos, la palabra de los poetas salvaguarda un brillo divino pero que se halla siempre, indefectiblemente, acechado por la opacidad de sus dobleces. No es sino desde ese espesor que le es dada la misión de "cantar" la suerte de los personajes más importantes de su tiempo: los sucesos vividos por los guerreros en las batallas, por los reyes en su gobierno, por los adivinos que vaticinan profecías, todos forman parte del material recurrente con el que componen sus versos y sólo existen como historias gracias a su pronunciación. Los poetas tienen el don de cantar la palabra y de hacer memoria; su fuerza decisiva es tal que, con sus versos, pueden hacer Elogio o Vituperio de lo acontecido, valorando o censurando una producción narrativa para siempre.

Este punto es muy importante, ya que en el centro de una cultura de la oralidad donde -al decir de Marcel Détienne ${ }^{22}$, todavía no se ha "democratizado" el empleo de la escritura ${ }^{23}$, el uso de la "palabra cantada" es la forma de asentir y de sostener una "memoria". Es preciso advertir, contra toda lectura modernista, que no se trata aquí de instaurar una memoria histórica que busque reconstruir el pasado según una perspectiva temporal, sino que el desafío reside, en cambio, en sostener la sacralidad de una memoria divina por medio de un relato. El canto de una "memoria sacralizada" es el privilegio que en la Grecia arcaica ostentan las cofradías de los hombres-poetas que preservan su recuerdo.

Tal como vimos, la "Memoria", al igual que los saberes de la Adivinación y los conocimientos de la Justicia, se conforma desde un saber mántico que compone su legitimidad a partir de su carácter total; don de visión, dijimos, que permitía atravesar todos los tiempos y todos los espacios posibles. Según nuestra lectura del legado de Homero, no es sino citando la fórmula "lo que es, lo que será, lo que fue" 24 como el poeta accede directamente a los acontecimientos que invoca. Su memoria es el privilegio de un "pasaje"

22 Détienne, M., op. cit., p. 67.

${ }^{23}$ No podemos negar -insiste Détienne (op. cit., p. 65)- que del siglo XII al IX la civilización griega no fue fundada sobre la escritura sino en las tradiciones orales.

${ }^{24}$ Homero, Iliada, I, 70; Hesíodo, Teogonía, 32 y 38. También Détienne (op. cit., p. 67) refiere al tema del poeta-vidente, retomando la lectura clásica de F. M. Cornford. 
entre mundos, de un contacto que le otorga el saber de "descifrar lo invisible": "La memoria, entonces, no es solamente el soporte material de la palabra cantada, la función psicológica que sostiene la técnica formular, es también y sobre todo, la potencia religiosa que confiere al verbo poético su estatuto de palabra mágico-religiosa." 25

La Memoria depende así de los poetas para producirse; con sus cantos escriben la historia. Al servicio del rey, del guerrero, de la Memoria, las Musas son las maestras de una decisión definitoria: qué episodios serán dignos de "Elogio" y cuáles serán objeto de "Vituperio". La tarea no es sencilla ya que estas dos potencias se encuentran siempre entremezcladas en la multiformidad de las cosas de la vida. Así lo asume Píndaro, quien reitera "El Elogio está al lado del Vituperio", asintiendo a la polaridad propia del mundo religioso en el que se inscribe su palabra poética. Una vez más se trata de sortear entre fuerzas ambivalentes la perdurabilidad del destino de los humanos. De esta manera, dirimiéndose entre E $\pi \alpha \imath v o \varphi$ y $М \omega \mu о \varphi$, entre la "alabanza" y la "reprobación" canta su eficacia la palabra del poeta, cuya búsqueda de reequilibrio es tarea de un constante arbitraje: “...rebatiendo el Vituperio tenebroso (...) traeré a un amigo, como una onda favorable, el elogio real de su gloria." 26

Los epinicios de Píndaro se cantan para conmemorar las victorias de los guerreros en las batallas o de los atletas en los Juegos Olímpicos: la luminosidad de la Alétheia toma la forma del elogio y enaltece al vencedor, a su equipo, a su patria, a la belleza recreada en los juegos. Esta palabra es meditación acerca de las condiciones de la victoria, es atención a los modos de una sabiduría que se expresa con la ejemplaridad del cortejo sintagmático de la Alétheia. "¿A qué dios, a qué héroe, a qué hombre cantaremos?" (Píndaro, Olímpica, II). La palabra de los poetas ejerce su poder transmutador: tan sólo basta su cadencia para volver dioses a los hombres.

En este sentido, es interesante tener en cuenta que el acceso a los valores de gloria, lejos de asentarse sobre los méritos de una única escala

25 Détienne, M., op. cit., p. 67. La traducción es propia.

26 Píndaro, Némeas, VII, 61-63. 
ascendente, también en este mundo se organiza tomando parte en el juego paradojal recuperado por otra pareja de nociones complementaria y ambivalente: Kleos y Kudos. Tal como explica Détienne ${ }^{27}$, en el imaginario griego la expectativa de los guerreros está circunscripta en la doble obsesión de crecer bajo los valores de estos dos aspectos de la gloria que puede traer el combate. Kudos, es la gloria que ilumina al vencedor, a la manera de una gracia divina instantánea. Son los dioses quienes deciden en pos de un resultado, otorgarla a unos y quitarla a otros. El otro valor de gloria, Kleos, precisa algo más de tiempo. Es la gloria que el "de boca en boca" va creando sosteniendo en su producción de phylia una palabra que promete circular de generación en generación. Détienne resume este doble juego en una frase muy ilustrativa: "...Si el Kudos viene de los dioses, el Kleos sube hasta ellos"28. En cualquier caso, sea que venga desde lo alto o que escale desde abajo, la gloria del guerrero no depende en ningún momento estrictamente de sí mismo, ni de la naturaleza de su accionar, sino del modo en el que se recepcionan los efectos de sus actos. Kudos legitima la fuente de un valor de gloria que es siempre divino; Kleos, el valor de gloria sostenido la circulación de sus elogios en su comunidad. Los poetas son los portavoces de esta doble fuerza, ellos median el esfuerzo humano para con los dioses, ellos median el heroísmo humano frente a los otros hombres. Actores decisivos de esta selectividad, son quienes pueden dar fuerza a la Alétheia para abrirse paso entre los juegos oscuros de Lethé, consolidando un relato victorioso, memorable, uniendo palabra eficaz con una acción al servicio de perpetuar una cierta historia, o lo que es lo mismo, la reproducción de un mismo discurso.

Détienne recuerda que esta actitud era obligatoria en una sociedad aristocrática: el elogio de la fuerza de los guerreros, de la riqueza de los reyes, del coraje de los nobles ${ }^{29}$ permitía continuar la herencia divina. Lo interesante y paradójico en este asunto reside en la envergadura que cobra esta misión cuando en Grecia comienzan a discutirse otros modos posibles de

\footnotetext{
${ }^{27}$ Détienne, op. cit., p. 74.

${ }_{28}$ Detienne, M., op. cit., p. 74. Traducción propia.

29 Píndaro, Némeas, I, 5-6; IV, 93; V, 19; XI, 17 y ss.; Píticas, I, 43; II, 66-67; Ístmicas, III, 7-8; V, 59; I, 43 y ss., etc.
} 
distribución de la palabra y otros modos posibles de realización de la acción. Es en la antesala constitutiva de los juegos de verdad que llevarán a la conformación de la polis clásica que la palabra-acción de los poetas replicará con más fuerza identificando el rayo de la Alétheia al centelleo elogiable de la memoria. Su rol es fundamental en un contexto en el que los hombres comienzan a plantear cuáles son los mejores modos de organización de la vida-con-otros. En la antesala de la polis clásica, el rol de los poetas resiste 'conservando' una palabra-acción que se quiere resguardar del intercambio dialógico naciente. Su práctica es fundamental al sostenimiento de un saber luminoso que irá dejando en el camino la ambivalencia de las opacidades que le son constitutivas para amenazarlas del afuera en el que las deja sumidas la lógica de no-contradicción proclamada por un 'ser que es y un no ser que no es'. La tarea de los poetas, en el sustrato arcaico de la polis, implícitamente viene a recordar el rayo de una eficacia divina cuidando al ser contra toda circunstancia: De esta manera, dice Détienne ${ }^{30}$, "[p]or la potencia de su palabra, el poeta hace de un simple mortal "un equivalente del Rey" ${ }^{1}$ : él le confiere el Ser, la Realidad; su elogio es calificado de etumos 32 ".

Para que triunfe la verdad y se haga memoria en este mundo complicado, es preciso asegurar la victoria del elogio de la Alétheia sobre la ironía opaca de Momos. "La palabra vive mucho más tiempo que los actos." (Píndaro, Némeas, IV, 6), Píndaro sabe sobre la importancia de los efectos de su misión histórica y pedagógica. Notablemente aquí la producción de memoria, aun si se quiere conservadora, no reclama el recurso a un origen: no es sino entre Mnémosine y Momos -entre las formas del elogio y las formas de la ironía- dónde va configurando la selección sus materiales. Es preciso atravesar las tinieblas que conforman el paisaje de Momos -su poder de vituperio, de censura, de reproche, de sarcasmo, de ironía, de silencio-, para legitimar la luminosidad de una palabra cantada al servicio del recuerdo. En este paisaje donde la memoria se va creando en un devenir de solapamientos y de pérdidas, el poeta es quien puede asumir que a menudo, “...los actos de

\footnotetext{
${ }^{30}$ Detienne, M., op. cit., p. 75. La traducción es propia.

31 Píndaro, Némeas, IV, 83-84.

32 Píndaro, Némeas, VII, 63; Píticas, I, 68.
} 
valor privados del himno de alabanza quedan cubiertos de una profunda oscuridad" (Némeas, VII, 12-13). La función de los poetas es de cabal importancia, ya que no ocurriría de otra manera, el hecho es que "los mortales son olvidadizos de todo lo que no ha tocado el arte supremo de los poetas, de lo todo lo que no han acarreado en sus ondas los versos que otorgan la gloria" (Ístmicas, VII, 16-19). Justamente, una vez más, "son estos cantos ilustres los que hacen durar el recuerdo del mérito" (Píticas, III, 114115).

Investido de una "misión sagrada", el poeta asume el carácter ambivalente de su rol. Por un lado, es quien sabe que debe respetar la Diké divina en las leyes de composición propias de las odas y de los epinicios, ya que es el modo en el que la Alétheia ratifica su presencia y por lo tanto, el criterio de legitimidad de la verdad en este mundo. Por otro lado, el poeta tiene la capacidad de crear novedad en medio del infinito juego de variaciones que las circunstancias presentan y de ir ajustándola cada vez de acuerdo a las posiciones de la phylia que sostendrá con su 'de boca en boca' esta memoria.

En un contexto que busca una producción de verdad de la mano de una palabra-acción sin desdeñar de la dinámica ambivalente de elogios y de ironías propia de todo lenguaje, de tejidos y destejidos propias de toda acción, Píndaro emerge como creador de una poesía gramaticalmente inestable, variable en la modalidad que escoge para sus formulaciones, astuto en los modos de aprovechamiento de kairós. El valor de sus creaciones, de las imágenes y yuxtaposiciones que nos legan sus odas y sus epinicios, reafirma la importancia del juego de entrar y salir -como las abejas de flor en flor-, de la multiplicidad de las circunstancias propias de la vida humana buscando asir lo verdadero. La memoria, de la mano de los poetas en este tiempo, es un arte de decisiones compositivas, de manejo de posiciones, es un saber de mezclas. Por esto mismo se lo inviste de la misión más excelsa: producir una palabra capaz de constituirse como acción decisiva en el mismo movimiento en que se pronuncia, garantizando la perpetuidad de esa eficacia, echando luz en un mundo confuso y que amenaza complicar cada vez más los juegos de palabras y de acciones que legitiman su producción verdadera. 


\section{Bibliografía}

-Benveniste, E. (1969). Le vocabulaire des institutions indo-européennes. Paris, Minuit.

-Boisacq, E. (1907). Dictionnaire étymologique de la langue grecque, Paris.

-Brugmann, K. (1905). "Verdunkelte Nominalkomposita des Griechischen und des Lateinischen", Ind. Forsch., 17.

-Chantraine, P. ([1968] 2009). Dictionnaire étymologique de la langue grecque. Histoire des mots. Paris, Editions Klincksieck.

-Cornford, F.M. (1952). Principium Sapientiae. The Origins of Greek Philosophical Thought, Cambridge.

-Degani, A. (1969). Aion da Omero ad Aristotele. Padova, CEDAM.

-Détienne, M. (2006). Les Maîtres de Vérité dans la Grèce Antique. Paris, Ed. Le Livre de Poche, Librairie Générale Française.

-Gallet, B. (1990). « Recherches sur kairós et l'ambiguïté dans la poésie de Pindare », Paris, Presses Universitaires de Bordeaux.

-Gaisford, T. (ed.), ([1848] 1965). Etymologicon magnum, seu, Verius lexicon: saepissime vocabulorum origines indagans ex pluribus lexicis scholiastis et grammaticis anonymi cuiusdam opera concinnatum. Oxford, University Press. Repr. Amsterdam.

-Gernet, L. (1968). Anthropologie de la Grèce Antique. Vol. 1, Paris, Maspero.

-Homero (2008). La Odisea. Madrid, Editorial SM.

-Kerkhoff, M. (1971). "Zum antiken Begriff des Kairós". Zeitschrift für Philosophische Forschung, 27, (2), pp. 256-274.

-Levi, D. (1924). "Kairós attraverso la literatura greca », Rend. dell' Acc. Nsaz, Lincei, 32, pp. 260-281.

-Liddell, H. G. y Scott, R. (comp.), (1968). A Greek-English Lexicon. Oxford, Clarendon Press. 
-Onians, J. (1996). Arte y pensamiento en la época helenistica: la visión griega del mundo (350 A.C. - 50 A.C.), Barcelona, Editorial Alianza.

-Passow, F. (1831). Handwörterbuch der Griechischen Sprache, Leipzig, Erster Band.

-Persson, P. (1891). Studien zur Lebre von der Wurzelerweiterung und Wurzelvariation. Uppsala, Universitets årsskrift, 4.

-Pindaro. (2002). Odas y fragmentos: Olimpicas; Piticas; Nemeas; Ístmicas; Fragmentos. Madrid, Gredos.

-Roscher, W. H. (1890-1894). Ausfübrliches Lexikon der Griechischen und Römischeb Mythologie. Leipzig, Druck und Verlag Von B. G. Teubner.

und Ärzte, Leipzig, 1906.

(1906). Die Hebdomadenlebren der griechischen Pbilosophen

-Trédé, M. (1992). Kairós. L'à-propos et l'occasion (Le mot et la notion, d'Homère à la fin du IV e siècle avant J.-C.). París, Éditions Klincksieck.

-Untersteiner, M. (1950). "Kairós come fonte del fatto poetico", en $L a$ Formazione poetica di Pindaro. Messina, Firenze, Casa Editrice G. D'Anna, pp. 65-102.

-Untersteiner, M. and F. J. Nisetich (1980). Pindar's Victory Songs, Baltimore, Johns Hopkins University Press.

-Vernant, J. P. (1959) « Aspects mythiques de la mémoire en Grèce », Journées de Psychologie, Paris.

Eudeba.

(1991). Los orígenes del pensamiento griego. Buenos Aires,

-Wilson, J. R. (1980), "Kairós as 'Due mesure”, Glotta LVIII.

Recibido: 12/2104. Aprobado: 5/2015 